\title{
Clinical and subclinical maternal hypothyroidism and their effects on neurodevelopment, behavior and cognition
}

Alice Batistuzzo'

https://orcid.org/0000-0003-2815-7504

Miriam Oliveira Ribeiro'

https://orcid.org/0000-0001-8637-676X

\section{ABSTRACT}

Clinical and subclinical hypothyroidism are the most common hormonal dysfunctions during pregnancy. Insufficient maternal thyroid hormones (THs) in the early stages of pregnancy can lead to severe impairments in the development of the central nervous system becauseTHs are critical to central nervous system development. In the fetus and after birth, THs participate in neurogenic processes, cell differentiation, neuronal activation, axonal growth, dendritic arborization, synaptogenesis and myelination. Although treatment is simple and effective, approximately $30 \%$ of pregnant women in Brazil with access to prenatal care have their first consultation after the first trimester of pregnancy, and any delay in diagnosis and resulting treatment delay may lead to cognitive impairment in children. This review summarizes the effects of clinical and subclinical hypothyroidism on fetal neurodevelopment, behavior and cognition in humans and rodents. Arch Endocrinol Metab. 2020;64(1):89-95

Keywords

Hypothyroidism; pregnancy; offspring; cognition; behavior
1 Departamento de Pós-Graduação em Distúrbios do Desenvolvimento, Centro de Ciências Biológicas e da Saúde (CCBS), Universidade Presbiteriana Mackenzie (UPM), São Paulo, SP, Brasil

Correspondence to:

Alice Batistuzzo

Laboratório de Neurobiologia

e Metabolismo Energético

Rua da Consolação, 930,

Prédio $28,1^{\circ}$ andar

alice.batistuzzo@gmail.com

Received on Sept/12/2019 Accepted on Nov/29/2019

DOI: 10.20945/2359-3997000000201

\section{INTRODUCTION}

$\mathrm{T}$ hyroid hormones (THs) are essential for the development, growth and metabolism of all vertebrates from the embryonic period onward. Thyroxine, or T4 $\left(3,5,3^{\prime}, 5^{\prime}\right.$-tetraiodothyronine), the principal product of the thyroid gland, is considered a prohormone from which triiodothyronine (T3) is derived by deiodination. $\mathrm{T} 3$ is an active $\mathrm{TH}$ capable of binding to high affinity receptors located in the nucleus of its target cells, the thyroid receptors (TRs). T3 is a biologically active hormone and is fundamental for growth, differentiation, activity regulation and organ and tissue metabolism, even in adult life (1).

The fetal thyroid becomes fully functional in humans from the second trimester of gestation. However, the fetus expresses TRs for THs from the 9th week (2), suggesting that THs are important even before the fetus is able to synthesize them. The source of THs during the first trimester is, therefore, exclusively maternal, and changes in TH availability may cause complications during pregnancy and have a negative effect on neurodevelopment, including consequences for behavior and cognition (3). The more severe the change, the greater the damage (4). However, controversy still exists regarding whether subclinical hypothyroidism ( $\mathrm{SCH}$ ) impacts the neurodevelopment and cognition of offspring.

\section{METHODS}

The review process took place between January and December 2018. The PubMed, Lilacs, Scopus and Web of Science databases were used with no restriction on the date of publication. A bibliographic search was conducted using the following keywords in English, Portuguese and Spanish: hypothyroidism, subclinical hypothyroidism, gestational, pregnancy, offspring, cognition, behavior and memory. Papers related to congenital hypothyroidism were excluded from the analysis.

\section{LITERATURE REVIEW}

The fetal thyroid and the role of THs in central nervous system development during pregnancy

THs are essential for the development, growth and metabolism of all vertebrates from the embryonic stage to adulthood. The thyroid gland, through its interaction 
with the thyroid stimulating hormone (TSH), which binds with membrane receptors present in the thyroid follicular cell, secretes two hormones: T4 and T3 (5).

Two pathways guarantee the production of adequate T3 levels: thyroid activity regulated by the hypothalamic-pituitary-thyroid system and peripheral T3 generation from T4, which depends on the action of specific enzymes called iodothyronine deiodinases. About $80 \%$ of circulating T3 is generated from T4 deiodination, whereas $20 \%$ is generated by the thyroid itself (6).

Deiodinase type 2 (D2) converts T4 to T3. It is highly expressed in the central nervous system (CNS), the pituitary gland, brown adipose tissue and the placenta and provides T3 for the tissues in which it is expressed. Deiodinase type 3 (D3) is primarily responsible for the degradation of THs through the conversion of $\mathrm{T} 4$ into reverse $\mathrm{T} 3(\mathrm{rT} 3)$ and the conversion of T3 into T2. In adults, it is found mainly in the CNS and in the skin, and its action is increased in hyperthyroidism. However, it is highly expressed in fetal tissues (7), the placenta (8), the gravid uterus and umbilical vessels (9), ensuring that the fetus is not overexposed to active T3 (10).
The thyroid is the first endocrine gland to be formed during embryonic development (11). Its organogenesis can be described in 3 phases (Figure 1).

Phase 1. This phase begins on the 20th day of embryonic development (E20) in humans and on the 8th day (E8) in mice, when endodermal thickening is observed on the floor of the pharynx, giving rise to a set of cells called the thyroid primordium. The thyroid primordium invaginates, forming the primitive thyroid bud, which begins its caudal migration. The coding genes for TTF-1, TTF-2 and PAX-8 are expressed at the beginning of glandular formation and are involved in the migration and proliferation process, but they are not dependent on T3 signaling $(12,13)$.

Phase 2. At the 7th week (E44-48) in humans and at the end of the 2nd week (E13-14) in mice, the thyroid bud reaches the final cervical position anterior to the trachea. At the end of the migration, the differentiation process depends on the progressive activation of thyroglobulin $(T G)$, thyroid peroxidase (TPO), TSH receptor $(T S H R)$, sodium/iodine symporter (NIS) and pendrin $(P D S)$, all of which are related to $\mathrm{TH}$ biosynthesis (11). From the 9th week (E63) in humans and Ell.5 in mice, the expression of the TRs (5) is

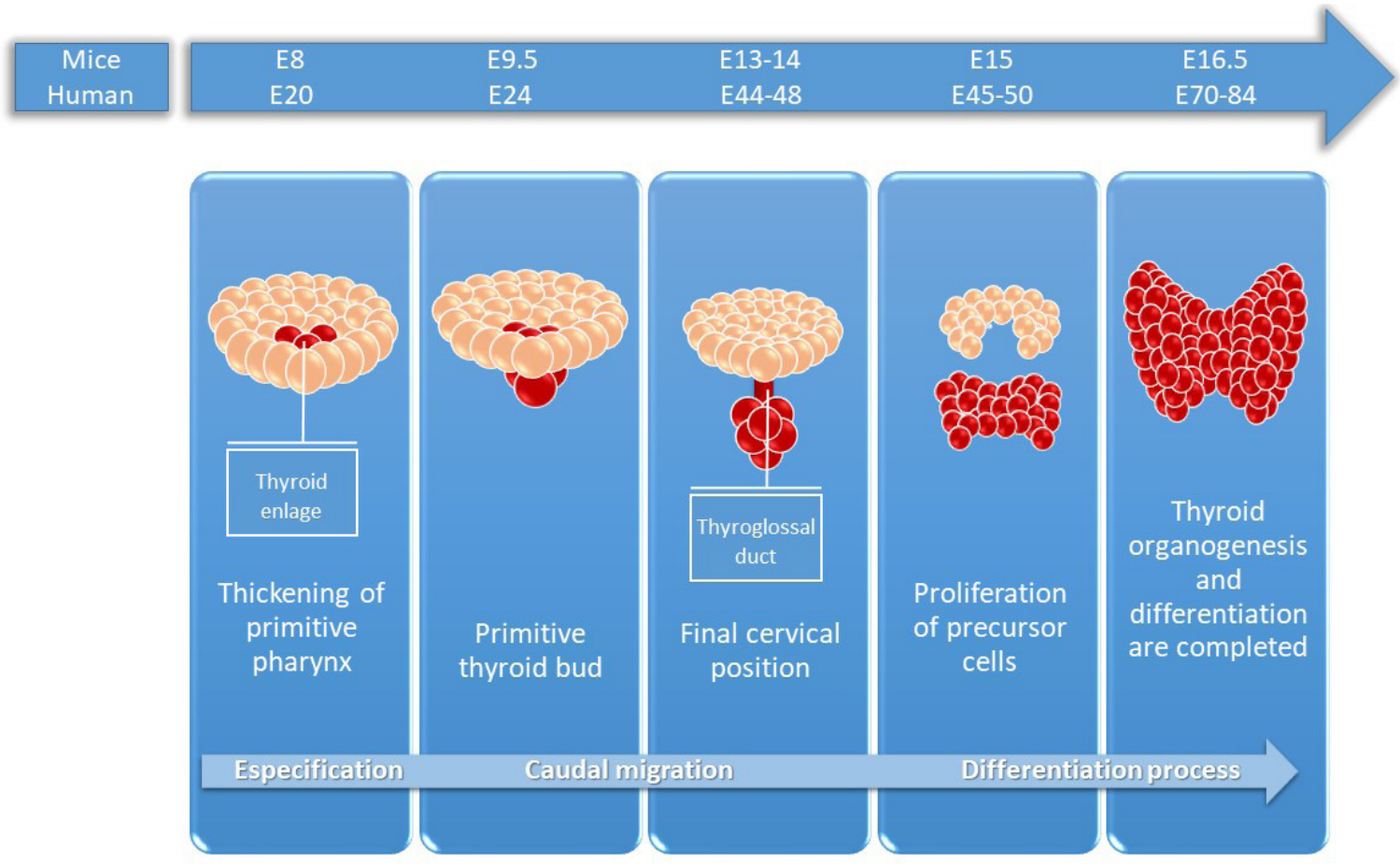

Figure 1. Main phases of thyroid development from the 8th day of embryonic development (E8) for mice and the 20th day of embryonic development (E20) for humans. 
already detectable. The TRs belong to a superfamily of hormone-responsive nuclear transcription factors and interact with specific sequences in target genes called thyroid hormone-responsive elements (TREs) (14). Interaction between the receptors and the responsive elements can regulate positive and negative gene expression. In the case of promoters containing positive TREs, T3 must bind to the TRs to stimulate gene expression that is usually suppressed in the absence of such binding (15). Conversely, the activity of promoters containing negative TREs is stimulated when the receptors are not bound to $\mathrm{T} 3$, and transcription is suppressed if T3 binds to the TRs (14,15).

Phase 3. During the period comprising the 10th (E70) and 12th weeks (E84) in humans and the third week in mice (E16.5), thyroid organogenesis and differentiation are completed. Between the 12th and 14th weeks of fetal development, the human thyroid begins producing THs. This increases progressively until reaching its maximum capacity at week 28 . In mice, the thyroid becomes active from E.16.5 $(11,16)$.

This sequence of events strongly suggests that maternal THs are critical to proper fetal development. The TH transporters organic anion-transporting polypeptide lcl (Oatplcl) and monocarboxylate transporter 8 (MCT8) are present in the placenta and the blood-brain barrier, which ensures their availability to the fetus (16-18).

From the 9th week of gestation, T3 of maternal origin regulates the neuronal proliferation processes and the initiation of neuronal migration in the cerebral cortex, hippocampus and medial ganglionic eminence in the fetus (Figure 2) (16,19). From the 14th week, the fetus starts to contribute progressively to TH supply. At this stage, neurogenesis, neuronal migration, axonal growth, dendritic arborization, synaptogenesis, glial cell differentiation and myelination onset occur (16).

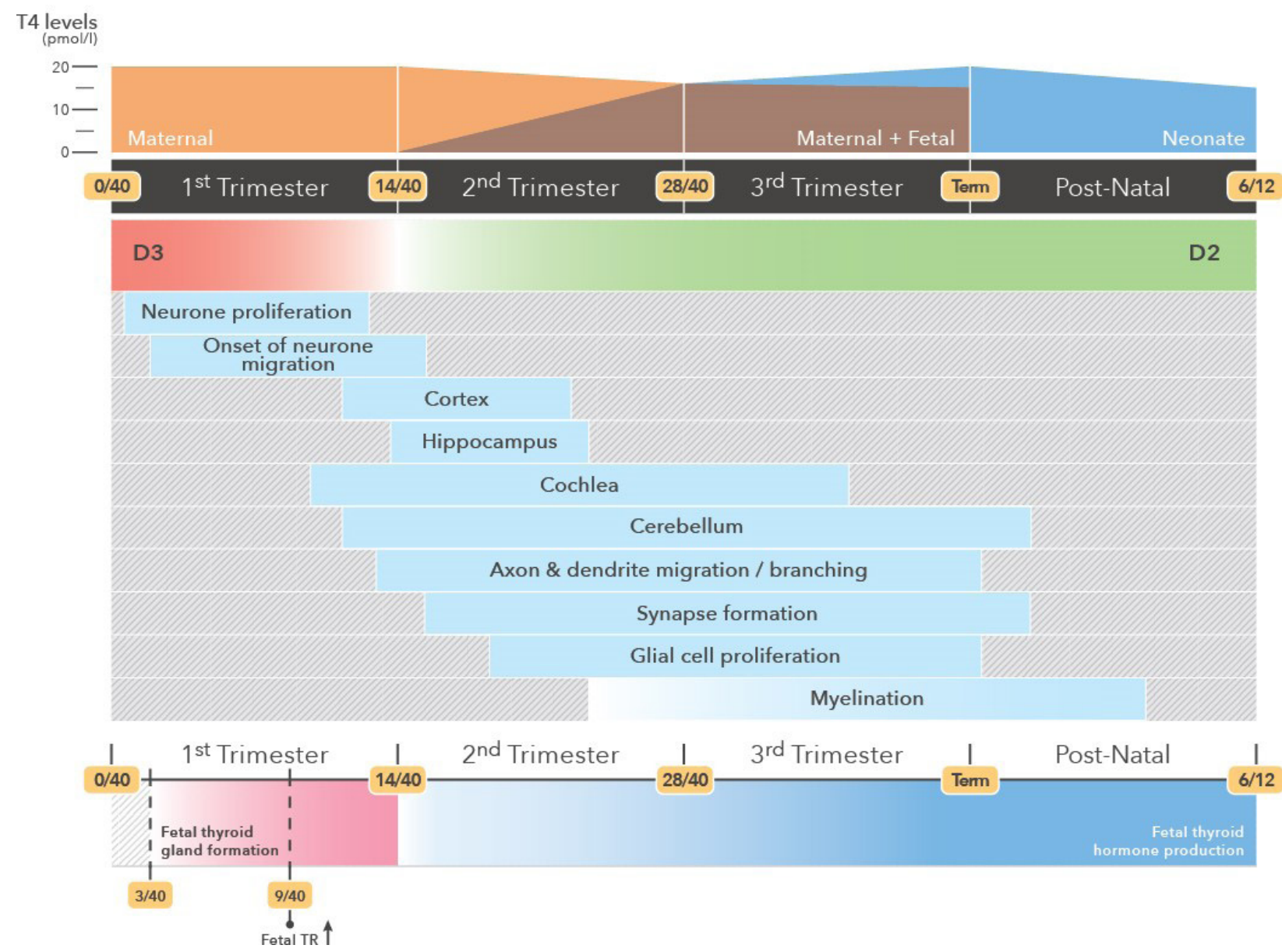

Figure 2. Development of fetal thyroid, expression of receptors, expression of deiodinases 2 and 3, levels of maternal and fetal T4 and CNS development throughout the gestational period in humans (adapted from [16]). 
From the 28th week, the mother and fetus contribute equally to available $\mathrm{TH}$ levels and to the ongoing maturation of the CNS. However, despite increasing fetal TH levels, the thyroid is not fully mature until birth, and insufficient maternal TH levels may still cause adverse effects $(12,16,19)$. After birth, the child depends exclusively on the synthesis of THs by its thyroid, and the process of myelination, the migration of granular cells in the dentate gyrus of the hippocampus and cerebellum, pyramidal cells in the cortex and Purkinje cells in the cerebellum continues (16).

It is reported in the literature that thyroid disorders during pregnancy are associated with severe maternal, fetal and neonatal complications such as miscarriage (20), preterm delivery (21) and preeclampsia (22).

\section{Maternal hypothyroidism}

During gestation, the demand for $\mathrm{TH}$ production by the maternal thyroid increases significantly, by approximately $20 \%$ to $50 \%$, to maintain a euthyroid state. During the first week of gestation, the placenta begins synthesizing human chorionic gonadotropin (hCG), which acts as a TSH receptor agonist. Maximum hCG concentration is reached between the 9th and 11th weeks, after which it decreases again, and a stable concentration is maintained from the 20th week. Simultaneously, there is an increase in thyroxinebinding globulin (TBG) levels and the action of type 3 deiodinase in the placenta. Together, these mechanisms result in increased maternal T4 serum concentration during the first trimester and a relative decrease over the second and third trimesters $(23,24)$. Thus, conditions that affect the adequate availability of T4 may affect both the mother and the fetus (25).

Clinical hypothyroidism $(\mathrm{CH})$ is defined as a situation in which subnormal free $\mathrm{T} 4$ levels is accompanied by TSH levels higher than $10 \mathrm{mIU} / \mathrm{L}$ (26), and its incidence ranges from 0.3 to $0.5 \%$ in pregnant women (27). Subclinical hypothyroidism ( $\mathrm{SCH})$ is defined elevated TSH ( $>4.5 \mathrm{mIU} / \mathrm{L}$ ) accompanied by normal free T4 levels (27). Its prevalence varies according to population, region, age, sex and race. Studies with large populations in various countries have reported a prevalence of 3 to $17 \%$ in the adult population, with higher frequencies in women and elderly people $(25,28)$. It has a high prevalence among pregnant women of between 2 and 4\% (29).

In pregnant women, the most common cause of $\mathrm{CH}$ and $\mathrm{SCH}$ is autoimmune thyroiditis (30).
In this situation, the increase in TSH is accompanied by an increase in anti-peroxidase (anti-TPO) and antithyroglobulin (anti-TBG) antibodies $(26,28)$. Other causes include iodine deficiency, thyroid destruction (iodine ablation or surgery), and - more rarely hypothalamic-pituitary disorders (31).

\section{Changes in neurodevelopment and cognition in humans due to hypothyroidism}

Maternal $\mathrm{CH}$ is associated with a number of adverse effects in the mother and child. Decreased THs in the fetus, especially during the first trimester of pregnancy, lead to fetal damage that includes impaired nerve cell differentiation, inadequate CNS development, increased risk of perinatal defects, low birth weight, and motor and cognitive developmental impacts $(15,25)$.

Both maternal $\mathrm{CH}$ and $\mathrm{SCH}$ can cause IQ reduction in the child (32). Vulsma and cols. (33) compared the development of 120 children born to mothers diagnosed with hypothyroidism at the 12th week of gestation during the first 2 years of life and found impairments in the children's motor and intellectual development compared to children born to euthyroid mothers. Korevaar and cols. (34) studied nearly 4,000 childmother pairs and reported that the children of mothers with hypo- and hyperthyroxinemia during pregnancy had significantly lower IQ scores than the children of mothers with adequate free T4. This decrease in IQ assessed at 6 years old - was accompanied by a reduction in gray matter and the volume of the cortex. Ghassabian and cols. (35) also observed a reduction in verbal and nonverbal cognitive development among children of mothers with hypothyroxinemia, but without changes in brain morphology.

SCH's impact on pregnant woman is better established than its impact on the fetus, and considerable controversy surrounds its influence on offspring cognition (36). It is associated with higher rates of placental abruption and increased risk of preterm birth (37), spontaneous abortion (38), gestational hypertension and severe preeclampsia (39).

Preterm birth is the most common cause of neuropsychological dysfunction in children and is associated with reduced IQ and attention deficit hyperactivity disorder $(40,41)$. Behavioral disorders such as aggression and emotional disorders such as depression and anxiety are often associated with low gestational age (41). 
Therefore, $\mathrm{SCH}$, by increasing the chances of preterm birth, may increase the chances of possible cognitive impairment, even if indirectly.

However, there is no consensus on whether treatment with levothyroxine (L-T4) efficiently prevents cognitive impairments. Haddow and cols. (32) suggested that increasing T4 doses during pregnancy for hypothyroid women may be sufficient to ensure the delivery of $\mathrm{T} 3$ and prevent the cognition impairments associated with low T4. However, Casey and cols. (42) found no better cognitive outcomes when comparing the offspring of treated and untreated women with $\mathrm{SCH}$ or hypothyroxinemia.

\section{Changes in neurodevelopment, gene expression and cognition in rodents}

Several studies involving rats and mice have demonstrated how maternal hypothyroidism influences cognitive function in offspring. Opazo and cols. (43) reported impairments in operational memory, spatial learning and changes in the expression and distribution of proteins involved in the formation of synapses in the offspring of hypothyroid rats, such as the discs large MAGUK scaffold protein $4(D \lg h-4)$ and glutamate ionotropic receptor NMDA type subunit l (Grinl).

Brain-derived neurotrophic factor $(B N D F)$ is an important protein involved in neurogenesis, neuronal maintenance and synaptic plasticity in the hippocampus, cortex and brain stem. It also promotes long-term potentiation (LTP) in the hippocampus (44). BDNF reduction in the hippocampus was correlated with impairment in spatial learning and operational memory in males and females born to mothers with $\mathrm{CH}$ (4547). This correlation is also found in the offspring of both sexes born to mothers with SCH (48).

Migration and differentiation processes are dependent on reelin, a glycoprotein involved in the signaling of neuronal migration in the cortex, hippocampus and cerebellum, and upregulated by the action of T3 (49). Both clinical and subclinical maternal hypothyroidism result in a decrease in reelin levels and aberrant neuronal migration in rats $(46,50)$. The impairment in learning and spatial memory can be reversed in rodents with L-T4 replacement during the initial period of fetal development, around embryonic day 13. However, if the replacement is performed later, the impairments are not reversed.

In addition, the gene that encodes the Sonic Hedgehog $(\mathrm{SHH})$ signaling protein is positively regulated by $\mathrm{T} 3$ and plays a key role in embryonic development. The $S H H$ signaling protein is involved in neurogenesis, the localization of dopaminergic and serotoninergic neurons, and the mediation of neuroprotective and neurotrophic effects in several types of neurons (49). In rats, maternal hypothyroidism results in reduced $S h h$ expression and changes in cerebellar morphology (51-53).

Several other proteins regulated by T3 are involved in memory and learning: EGR -1 is a transcription factor that increases significantly during the LTP process; the activity-regulated cytoskeletal protein $(A R C)$ is involved with post-learning neuronal plasticity through the dendritic system; and Ras-proximate-l protein $(R A P-I)$ participates in the processes of proliferation and neuronal survival, adhesion and differentiation (54). Mitogen-activated protein kinases (MAPK) also constitute a family of important neurotransmitters and growth factor-activated markers, such as the MAPK activating protein $(M E K)$ and the extracellular signal regulated kinase (ERK) (54).

In rats with $\mathrm{CH}$ and $\mathrm{SCH}$, the expression of Egr-1, Arc, Erk and Bndf in their offspring's hippocampus was significantly decreased, and RAP-I levels were increased when compared to the offspring of euthyroid rats, although this was more pronounced in the HC roup. Changes in these proteins' expression are accompanied by impairments in spatial learning evaluated using the water maze test and exploratory behavior evaluated using the open field test. These effects probably occur because these proteins are part of the Ras/Raf/MEK/ERK signaling pathway, which is involved in the LTP process $(54,55)$.

In another study, a contradictory finding was observed in which increased Erk 1/2 protein levels were found in the hippocampus of the offspring of rats with SCH. The authors argued that this discrepancy in the data, in which Erk levels appears to sometimes increase and sometimes decrease, was caused different experimental designs, such as the hippocampal region analyzed, the time elapsed since the thyroidectomy, whether the thyroidectomy was partial or total and the analyses performed (55).

The consequences of gestational $\mathrm{CH}$ for both mother and offspring are widely recognized, and hormone replacement therapy with L-T4 is recommended. However, there is still some debate regarding the treatment of pregnant women diagnosed with SCH (42). Some authors argue that the treatment 
of pregnant women with $\mathrm{SCH}$ is not recommended due to lack of evidence and randomized clinical trials on the benefits of levothyroxine replacement for both mother and fetus $(37,56,57)$.

\section{CONCLUSION}

In conclusion, the consequences for CNS development and cognition caused by insufficient maternal THs in $\mathrm{CH}$ are well known in humans and have been established experimentally in rodents. However, rodent studies indicate that SCH also impacts cognitive development.

Since 2000, the Brazilian Ministry of Health has recommended a minimum of 6 prenatal consultations, according to the Programa de Humanização no Prénatal e Nascimento (PHPN), the Program for the Humanization of Prenatal Care and Childbirth (58). However, the 2018 Firjan Municipal Development Index (FDI) reported that, in 2016, one-third of pregnant women did not receive the recommended minimum number of prenatal consultations (59). In 2014, an epidemiological study conducted in Brazil indicated that, among pregnant women who received prenatal care, $24.2 \%$ started it after the $16^{\text {th }}$ gestation week (60). Therefore, monitoring thyroid status throughout pregnancy, especially during the first trimester, is essential to ensuring adequate fetal development. Although prenatal TH testing should be routine to allow for the timely identification and treatment of any changes, not all pregnant women have adequate access to exams. More studies are necessary to evaluate whether $\mathrm{SCH}$ impacts cognition and behavior in humans, as studies in animal models mimicking this pathology have shown damage to the fetus.

Acknowledgments, funding and disclosure: the authors declare that they have no financial or other conflict of interest. PROEX Number/Author: 88887.184887/2018-00. FAPESP process number: $2017 / 18277-0$.

\section{REFERENCES}

1. Abdalla SM, Bianco AC. Defending plasma T3 is a biological priority. Clin Endocrinol (Oxf). 2014;81(5):633-41.

2. Bernal J, Pekonen F. Ontogenesis of the nuclear 3,5,30-triiodothyronine receptor in the human fetal brain. Endocrinology. 1984;114(2):677-9.

3. Maraka S, Ospina NMS, O'Keeffe DT, Espinosa De Ycaza AE, Gionfriddo MR, Erwin PJ, et al. Subclinical Hypothyroidism in Pregnancy: A Systematic Review and Meta-Analysis. Thyroid. 2016;26(4):580-90.
4. Gilbert ME, Lasley SM. Developmental thyroid hormone insufficiency and brain development: A role for brain-derived neurotrophic factor (BDNF)? Neuroscience. 2013;239:253-70.

5. Morvan-Dubois G, Fini JB, Demeneix BA. Is Thyroid Hormone Signaling Relevant for Vertebrate Embryogenesis? 1st ed. Vol. 103, Current Topics in Developmental Biology. Elsevier Inc.; 2013. 365-396 $\mathrm{p}$

6. Bianco AC, Kim BW. Deiodinases: implications of the local control of thyroid hormone action. J Clin Invest. 2006;116(10):2571-9.

7. Roti $\mathrm{E}$, Fang $\mathrm{S}$, Green $\mathrm{K}$, Braverman LE, Emerson $\mathrm{CH}$. Inner ring deiodination of thyroxine and by human fetal membranes. Am J Obstet Gynecol. 1983;147(7):788-92.

8. Roti E, Fang SL, Green K, Emerson CH, Braverman LE. Human Placenta Is an Active Site of Thyroxine and 3,3'5-Triiodothyronine Tyrosyl Ring Deiodination*. J Clin Endocrinol Metab. 2015;53(3):498-501.

9. Galton VA, Bates JM, St DL, Galton VA, Martinez E, Hernandez $A$, et al. Pregnant rat uterus expresses high levels of the type 3 iodothyronine deiodinase Find the latest version: Pregnant rat uterus expresses high levels of the type 3 iodothyronine deiodinase. J Clin Invest. 1999;103(7):979-87.

10. Huang SA, Dorfman DM, Genest DR, Salvatore D, Larsen PR, Endocrinology D, et al. Type 3 lodothyronine Deiodinase Is Highly Expressed in the Human Uteroplacental Unit and in Fetal Epithelium. J Clin Endocrinol Metab. 2003;88(3):1384-8.

11. Ramos $H$, Nesi-França $S$, Maciel R. Novos aspectos da genética e dos mecanismos moleculares da morfogênese da tiróide para o entendimento da disgenesia tiroidiana. Arq bras endocrinol metab. 2008;52/9(1):1403-15.

12. Trueba SS, Czernichow $P$, Vekemans $M$, Polak M, Attie T. during Human Development: New Insights into Human Thyroid Development andThyroid Dysgenesis-Associated Malformations. 2005;90(1):455-62.

13. Kambe F, Seo H. Thyroid-Specific Transcription Factors. Endocr J. 1997;44(6):775-84.

14. Cheng SY, Leonard JL, Davis PJ. Molecular aspects of thyroid hormone actions. Endocr Rev. 2010;31(2):139-70.

15. Zhang J, Lazar MA. The mechanism of action of the thyroid hormones. Annu Rev Physiol. 2000;62(1):439-66.

16. Williams GR. Neurodevelopmental and neurophysiological actions of thyroid hormone. J Neuroendocrinol. 2008;20(6):78494.

17. Friesema ECH, Docter $R$, Moerings EPCM, Stieger $B$, Hagenbuch $\mathrm{B}$, Meier PJ, et al. Identification of Thyroid Hormone Transporters 1. Biochem Biophys Res Commun. 1999;501:497-501.

18. Friesema ECH, Ganguly S, Abdalla A, Fox JEM, Halestrap AP, Visser TJ. Identification of Monocarboxylate Transporter 8 as a Specific Thyroid Hormone Transporter *. J Biol Chem. 2003;278(41):40128-35.

19. Morreale De Escobar G, Morreale De Escobar G, Obregon MJ, Obregon MJ, Escobar Del Rey F, Escobar Del Rey F. Role of thyroid hormone during early brain development. Eur $\mathrm{J}$ Endocrinol. 2004;151 Suppl:U25-37.

20. Negro R, Stagnaro-Green A. Clinical Aspects of Hyperthyroidism, Hypothyroidism, and Thyroid Screening in Pregnancy. Endocr Pract. 2014;20(6):597-607.

21. Zhou M, Wang M, Li J, Luo X, Lei M. Effects of thyroid diseases on pregnancy outcomes. Exp Ther Med 18. 2019;18(3):1807-15.

22. Päkkilä $F$, Männistö $T$, Pouta $A$, Hartikainen $A L$, Ruokonen $A$, Surcel HM, et al. The impact of gestational thyroid hormone concentrations on ADHD symptoms of the child. J Clin Endocrinol Metab. 2014;99(1):1-8.

23. Gouveia S, Leitão F, Ribeiro $C$, Carrilho F. Fatores de interferência no estudo da função tiroideia. Rev Port Endocrinol Diabetes e Metab. 2016;11(2):277-86. 
24. Medici M, Korevaar TIM, Edward Visser W, Visser TJ, Peeters RP. Thyroid function in pregnancy: What is normal? Biochim Clin. 2016;40(4):383-92.

25. Springer D, Jiskra J, Limanova Z, ZimaT, Potlukova E. Thyroid in pregnancy: From physiology to screening. Crit Rev Clin Lab Sci. 2017;0(0):1-15.

26. Garber JR, Cobin RH, Gharib H, Hennessey JV, Klein I, Mechanick $\mathrm{JI}$, et al. Clinical Practice Guidelines for Hypothyroidism in Adults: Cosponsored by the American Association of Clinical Endocrinologists and the American Thyroid Association. Thyroid. 2012;22(12):1200-51.

27. Budenhofer BK, Ditsch N, Jeschke U, Gärtner R, Toth B. Thyroid (dys-)function in normal and disturbed pregnancy. Arch Gynecol Obstet. 2013;287(1):1-7.

28. Kim YA, Park YJ. Prevalence and risk factors of subclinical thyroid disease. Endocrinol Metab (Seoul). 2014;29(1):20-9.

29. Biondi B. Natural history, diagnosis and management of subclinical thyroid dysfunction. Best Pract Res Clin Endocrinol Metab. 2012;26(4):431-46.

30. Tingi E, Syed AA, Kyriacou A, Mastorakos G, Kyriacou A. Benign thyroid disease in pregnancy: A state of the art review. J Clin Transl Endocrinol. 2016;6:37-49.

31. Costa SM, Netto LS, Buescu A, Vaisman M. Hypothyroidism in pregnancy. Rev Bras Sáude Matern e Infant. 2004;4(4):351-8.

32. Haddow JE, Palomaki GE, Allan WC, Williams JR, Knight GJ, Gagnon J, et al. Maternal Thyroid Deficiency during Pregnancy and Subsequent Neuropsychological Development of the Child. N Engl J Med. 1999;341(8):549-55.

33. VulsmaT, Baar AL Van, Vijlder JJ De. Maternal hypothyroxinaemia during early pregnancy and subsequent child development a 3-year follow-up study - Pop - 2003 - Clinical Endocrinology Wiley Online Library. 2003;(January 1997):282-8.

34. Korevaar TIM, Muetzel R, Medici M, Chaker L, Jaddoe VW V, De Rijke YB, et al. Association of maternal thyroid function during early pregnancy with off spring $\mathrm{IO}$ and brain morphology in childhood: a population-based prospective cohort study. Artic Lancet Diabetes Endocrinol. 2016;4(4):35-43.

35. Ghassabian A, El Marroun H, Peeters RP, Jaddoe VW, Hofman A, Verhulst FC, et al. Downstream effects of maternal hypothyroxinemia in early pregnancy: Nonverbal $\mathrm{IO}$ and brain morphology in school-age children. J Clin Endocrinol Metab. 2014;99(7):2383-90.

36. Baumgartnera C, Bluma MR, Rodondia N. Subclinical hypothyroidism: Summary of evidence in 2014. Swiss Med Wkly. 2014;144(December):1-9.

37. Casey BM, Dashe JS, Wells CE, McIntire DD, Byrd W, Leveno $\mathrm{KJ}$, et al. Subclinical hypothyroidism and pregnancy outcomes. Obstet Gynecol. 2005;105(2):239-45.

38. Benhadi N, Wiersinga WM, Reitsma JB, Vrijkotte TGM, Bonsel GJ. Higher maternal TSH levels in pregnancy are associated with increased risk for miscarriage, fetal or neonatal death. Eur J Endocrinol. 2009;160(6):985-91.

39. Wilson KL, Casey BM, McIntire DD, Halvorson LM, Cunningham FG. Subclinical thyroid disease and the incidence of hypertension in pregnancy. Obstet Gynecol. 2012;119(2):315-20.

40. Bhutta AT, Cleves MA, Casey PH, Cradock MM, Anand KJS. Cognitive and behavioral outcomes of school-aged children who were born preterm: a meta-analysis. Jama. 2002;288(6):728-37.

41. Johnson S. Cognitive and behavioural outcomes following very preterm birth. Semin Fetal Neonatal Med. 2007;12(5):363-73.

42. Bm C, EaT, Am P, Mw V, Sorokin Y, Dg H. Clinical Levothyroxine Therapy of Subclinical Hypothyroidism or Hypothyroxinemia in Pregnancy Does Not Improve Cognitive Function in the Offspring. Clin Thyroid. 2017;29(4):132-5.
43. Opazo MC, Haensgen $H$, Bohmwald $K$, Venegas LF, Boudin $H$, Elorza AA, et al. Imprinting of maternal thyroid hormones in the offspring. Int Rev Immunol. 2017;0185(March):1-16.

44. Gazzaniga MS. The New Cognitive Neuroscience. Vol. 53, Journal of Chemical Information and Modeling. 2000. 1689-1699 p.

45. Chakraborty G, Magagna-Poveda A, Parratt C, Umans JG, MacLusky NJ, Scharfman HE. Reduced hippocampal brain-derived neurotrophic factor (BDNF) in neonatal rats after prenatal exposure to propylthiouracil (PTU). Endocrinology. 2012;153(3):1311-6.

46. Lu L, Yu X, Teng W, Shan Z. Treatment with levothyroxine in pregnant rats with subclinical hypothyroidism improves cell migration in the developing brain of the progeny. $J$ Endocrinol Invest. 2012;35(5):490-6.

47. Shafiee SM, Vafaei AA, Rashidy-Pour A. Effects of maternal hypothyroidism during pregnancy on learning, memory and hippocampal BDNF in rat pups: Beneficial effects of exercise. Neuroscience. 2016;329:151-61.

48. Liu D, Teng W, Shan Z, Yu X, Gao Y, Wang S, et al. The effect of maternal subclinical hypothyroidism during pregnancy on brain development in rat offspring. Thyroid. 2010;20(8):909-15.

49. Bernal J. Thyroid hormone regulated genes in cerebral cortex development. J Endocrinol. 2016;232(2):R83-97.

50. Pathak A, Sinha RA, Mohan V, Mitra K, Godbole MM. Maternal thyroid hormone before the onset of fetal thyroid function regulates reelin and downstream signaling cascade affecting neocortical neuronal migration. Cereb Cortex. 2011;21(1):11-21.

51. Desouza LA, Sathanoori M, Kapoor R, Rajadhyaksha N, Gonzalez $L E$, Kottmann $A H$, et al. Thyroid hormone regulates the expression of the sonic hedgehog signaling pathway in the embryonic and adult mammalian brain. Endocrinology. 2011;152(5):1989-2000.

52. Wang $Y$, Wang $Y$, Dong J, Wei $W$, Song $B$, Min $H$, et al. Developmental hypothyroxinemia and hypothyroidism reduce proliferation of cerebellar granule neuron precursors in rat offspring by downregulation of the sonic hedgehog signaling pathway. Mol Neurobiol. 2014;49(3):1143-52.

53. Thiel G, Mayer SI, Müller I, Stefano L, Rössler OG. Egr-1-A Ca2+regulated transcription factor. Cell Calcium. 2010;47(5):397-403.

54. Adams JP, Sweatt JD. MOLECULAR PSYCHOLOGY: Roles for the ERK MAP Kinase Cascade in Memory. Annu Rev Pharmacol Toxicol. 2002;42(1):135-63.

55. Ge JF, Peng L, Hu CM, Wu TN. Impaired Learning and Memory Performance in a Subclinical Hypothyroidism Rat Model Induced by Hemi-Thyroid Electrocauterisation. J Neuroendocrinol. 2012;24(6):953-61.

56. Holtmann M, Duketis E, Goth K, Poustka L, Boelte S. Severe affective and behavioral dysregulation in youth is associated with increased serum TSH. J Affect Disord. 2010;121(1-2):184-8.

57. Sgarbi JA, Teixeira PF, Maciel LMZ, Mazeto GM, Vaisman M, Junior RMM, et al. Consenso brasileiro para a abordagem clínica e tratamento do hipotireoidismo subclínico em adultos: recomendações do Departamento de Tireoide da Sociedade Brasileira de Endocrinologia e Metabologia. Arq Bras Endocrinol Metab. 2013;57(3):166-83.

58. Ministério Da Saúde. Portaria $n^{\circ} 569$ de 01 de junho de 2000. Instituição do Programa de Humanização do Pré-natal e Nascimento no âmbito do Sistema Único de Saúde. Diário Oficial da República Federativa do Brasil. 1 de jun de 2000. http://bvsms. saude.gov.br/bvs/saudelegis/gm/2000/prt0569_01_06_2000_rep. html. Acessed in 10 FEB 2018

59. Índice Firjam deDesenvolvimento Municipal(IFDM).2018. https://www. firjan.com.br/data/files/67/A0/18/D6/CF834610C4FC8246F8A809C2/ IFDM_2018.pdf. Acessed in 10 FEB 2018

60. Fernandes Viellas E, Maria Soares Madeira Domingues R, Augusto Bastos Dias M, Granado Nogueira da Gama S, Miranda Theme Filha M, Viana da Costa J, et al. Assistência pré-natal no Brasil. Cad Saude Publica. 2014;30(s):85-100. 